\title{
VZDĚLÁVACÍ SYSTÉM A ČESKOSLOVENSKÁ VERZE PŘESTAVBY (1987-1989): ANALÝZA, KRITIKA A NÁVRHY NA REFORMY V KONTEXTU IDEOLOGIE A KRIZE
}

\author{
EDUCATION AND THE CZECHOSLOVAK \\ FORM OF PERESTROIKA (1987-1989): \\ ANALYSIS, CRITICISM, AND PLANNED \\ REFORMS IN THE CONTEXT OF IDEOLOGY \\ AND CRISIS
}

OTO POLOUČEK, JIŘÍ ZOUNEK

\begin{abstract}
Abstrakt
Autoři se zaméruji na pokusy o reformy vądélávaci soustavy v kontextu prosazováni prestavby v Ceskoslovensku. Analyzuji zejména archivni záznamy o problubujicich se problémech vadélávaci soustavy a možnostech jejich rè̌eni z.perspektivy státni moci. Problémy prosazování jednotné školy vedly ke zpracováni analýz. výchovné vz̆dělávaci soustavy a následné prípravě novel školských zákonü. Autori studie sleduji balancováni mezi ideologii a praktickými problémy školstvi, keteré možnosti blubšich reforem limitovalo, a reflektuji možné paralely s postsocialistickou transformaci (odrážejici se napríklad v prosazováni decentralizace rízeni škol). Nejnovèjši odborné reflexe pádu socialismu v Ceskoslovensku kladou dioraz právě na sledování kontinuit - autori tyto teze promýslejí, problubuji ve vatabu ko oblasti vzdéláváni a snaži se odpovédèt na otázku, zda mély reformy šanci na úspéch (pričemž bledaji paralely is vývojem v zabraničí).
\end{abstract}

Klíčová slova

školství, reforma, socialistické Ceskoslovensko, prestavba, archiv

\section{Abstract}

The authors focus on the educational reform proposals in the context of the perestroika policy in Czechoslovakia. In particular, they analyze the archival records reflecting the ongoing issues of the educational system from the perspective of state power. Problems with applying a united school policy led to several analyses of the educational system and the subsequent preparation of amendments to the school laws. The study examines the balance 
between communist ideology and the practical issues of schooling that limited the opportunities to effectively push more fundamental reforms. The authors also reflect possible parallels with the post-socialist transformation (e.g., in efforts to decentralize school management). The most recent perspective of contemporary history focused on possible continuities - the authors deepen this in terms of education and try to answer whether the proposed reforms could be successful, taking account of the parallels abroad.

\section{Keywords}

schooling, reform, socialist Crechoslovakia, perestroika, archive

\section{Úvod - širší kontexty narativu přestavby}

Změny po sametové revoluci roku 1989 v Československu vedly k zásadnímu obratu ve společenském konsenzu o uspořádání státu. Ukončily jakékoli předchozí úsilí o úpravu nefunkčního centrálně plánovaného hospodářství státního socialismu. Opatrné reformy byly přitom připravovány a zčásti aplikovány již v letech 1987 až 1989, tedy v období tzv. specifického československého pojetí př́estavby. Tyto pokusy byly silně svázány i omezeny ideologickými dogmaty (obzvláště nepřekročitelností Poučeni z križového vívoje). Současně byly doprovázeny disproporcí představ o podobě a šíri reforem u politických elit (zejména předsednictva Ústředního výboru Komunistické strany Československa - dále ÚV KSČ) a odpovědných osob (stranických funkcionářů, zástupců administrativy na vládní i regionální úrovni, kteří se přímo setkávali s dopady nefunkčního systému na ekonomiku a společnost). (Pullmann, 2011; Rychlík, 2020) V odborných kruzích (a obzvláště v Prognostickém ústavu ČSAV) pak již v této době krystalizovaly myšlenkové proudy prosazující nevyhnutelnost implementace tržního mechanismu do socialistické ekonomiky, které mohly po roce 1989 vyplynout v dominanci neoliberální hegemonie ${ }^{1}$ preferující neregulovaný volný trh. Sledování této kontinuity tvoří pilî́r nejnovějších interpretací konce socialismu v Československu a etablování nového politického systému po roce 1989 (srov. Berend, 2009; Pullmann, 2011; Rákosník et al., 2018; Sommer, 2019). Jejím východiskem je i předpoklad, že hypernormalizovaný systém pozdního socialismu čím dál více fungoval jako jakási formální fikce, jazyková skořápka, pod níž mohly skrytě růst alter-

Neoliberální hegemonií je myšlen import a prosazení politik thatcherovské Velké Británie a reaganovské Ameriky založené na ekonomických koncepcích Friedricha von Hayeka či Miltona Friedmana. Tato poměrně experimentální koncepce založená na výrazné regulaci poválečného sociálního státu za účelem dosažení ekonomického růstu a vyšší efektivity je politickými elitami ve střední a východní Evropě přijata jako něco přirozeného a samozřejmého (Berend, 2009; Kopeček, 2019). 
nativní myšlenkové proudy, a to zejména v expertních kruzích působících v rámci technokratického státního aparátu či na akademické půdě, tedy nikoli v oblasti disentu, který stál až do roku 1989 mimo veřejnou diskuzi a byl do posledních dnů tvrdě pronásledován tajnou policií. Vlivem toho se socialismus zdál být až do konce svých dnů věčným, aby pak velká část společnosti rychle nabyla pocitu, že byl konec vlády KSČ neodvratný - ideová hradba se rozpadala jako zmíněná křehká skořápka (srov. Houda, 2019; Jurčak, 2018).

Zatímco kontinuita mezi pozdním socialismem a postsocialistickou transformací v oblasti hospodářství, podnikového řízení či dokonce kultury již byla odborně zpracována, oblast vzdělávání na odbornou reflexi stále čeká. Připravované a z malé části aplikované reformy konce 80. let doposud nebyly dostatečně odborně zhodnoceny - a pokud je odborné texty zmiňují, jedná se o informace související s širším zájmem o dějiny socialistického či postsocialistického školství (srov. Moree, 2013; Rýdl, 2006; Vorlíček, 2004; Walterová, 2004; Zounek et al., 2017).

Zmíněnou mezeru se snaží alespoň částečně zaplnit tato empirická studie, která si klade za cíl na základě kritické analýzy dostupných písemných pramenů představit a do širšího kontextu zasadit připravované reformy vzdělávacího systému, které měly být uplatněny po zpracování jeho analýzy v roce 1988 a po 13. zasedání ÚV KSČ ke školství v březnu 1989. Stále ostřejší kritika vzdělávacího systému a navrhované reformy budou promýšleny i v souvislosti s debatami vedenými po roce 1989. Lze přitom sledovat mnoho paralel i naprosto protikladné příčiny neúspěchu, které však - jak ukáže tato studie - mají společného mnohem více než se na první pohled zdá. Neměnný ideologický konsenzus byl po roce 1989 vystřídán razantním odmítnutím doposud aplikovaného systému jednotné školy jako celku a nepružné diskuze nahradila živelnost. ${ }^{2}$ Některé zásadní problémy však přetrvaly. Předkládaná studie tak slouží jako teoretické východisko k hlubšímu pochopení událostí těsně před sametovou revolucí i po ní, a to v rámci postsocialistické transformace základního školství. Zaměříme se přitom zejména na perspektivy státní moci - KSČ a jí podřízené vlády na republikové i federální úrovni.

\footnotetext{
2 V této studii pracujeme s pojmem jednotná škola: ten spočívá na principu poskytování obsahem i kvalitou rovnocenného vzdělávání veškeré populaci mládeže od zahájení povinné školní docházky do určitého věku, a to ve školské instituci téhož typu (Průcha et al., 2009). V prrípadě tehdejšího Československa šlo o jednotnou vnitřně nediferencovanou školu, jejímiž hlavními znaky byla unifikace a malá obsahová diferenciace (Průcha, 2009). Obsah byl navíc silně ovlivněn či deformován dobovou ideologií apod. Od roku 1948 (Zákon č. 95/1948 Sb.) lze mluvit i o jednotné školské soustavě, která měla zajistit rovné právo všech lidí na vzdělání. Navíc byla tímto zákonem poprvé v naší historii zajištěna průchodnost školské soustavy od předškolního vzdělávání až po nejvyšší stupně vzdělávání (Walterová, 2004), což dříve nebylo možné.
} 


\section{Československá verze přestavby}

Od roku 1987 lze datovat československý odraz politiky perestrojky prosazované již od roku 1984 sovětským vůdcem Michailem Gorbačovem za účelem zefektivnění ekonomiky topící se ve stále větší krizi. Samotný koncept specifického „československého pojetí prrestavby“ (Pullmann, 2011, s. 63) souvisí s obavou vedení KSČ o narušení ideologického konsenzu, at’ již ze strany sovětské vlády, tak při bezpodmínečném přebírání sovětského př́stupu. Vláda svoji pomyslnou legitimitu delegovala na text Poučení z krizového vývoje ve straně a společnosti po XIII. sjezdu KSČ odmítající reformní kurz pražského jara a schvalující okupaci vojsk Varšavské smlouvy z roku 1968 jako „přátelskou pomoc“. Proto dlouho odmítala připustit, aby se v Československu odehrály procesy podobné reformnímu kurzu pražského jara (Rákosník et al., 2018) a vývoj v Sovětském svazu byl přijímán s obavami (McDermott, 2015). ${ }^{3} \mathrm{~V}$ roce 1987 pak československá vláda přijala přsestavbu pod tlakem ze SSSR, které mělo a mbici reformovat celý systém Rady vzájemné hospodářské pomoci (RVHP) (Pullmann, 2011).

Přestavba se v Československu měla nést výhradně v ekonomické rovině a měla vést k zefektivnění zaostávajícího hospodářství. Na úrovni ÚV KSČ na jedné straně a federální i republikové vlády a místních funkcionárư na straně druhé se však lišily motivace a cíle, které doprovázely aplikaci ekonomických reforem. ÚV KSČ si chtěl udržet svoji mocenskou pozici pomocí osvojení jazyka přestavby a jeho implementaci do ideologického konceptu. Naopak ti, kteří sami pocit’ovali problémy spjaté s nefunkčním systémem, si od reforem slibovali více. Doufali, že pomohou řešit problémy, se kterými se na každodenní bázi setkávali (McDermott, 2015). Málokdo měl však představu o tom, jak opatření implementovat, bez změny pilírư ideologie (Pullmann, 2011).

Ideologický jazyk byl obohacen o pojmy jako je „hospodářská decentralizace“ nebo „demokratizace“ (Pullmann, 2011), což se odrazilo i v podobě, v jaké oficiální dokumenty hovoří o školství a vzdělávání. Cílem KSČ bylo zabránit společenské destabilizaci - vývoj byl ale spíše opačný. Lidé pocit’ovali problémy na každodenní bázi a častější kritika neefektivity socialismu v denním tisku jim dávala jistou naději na změnu (Green, 2014). Rozčarování z absence bezprostředního dopadu na kvalitu života v souladu s evidentní nekompetencí čelních představitelů státu napomohlo k uvědomění, že narativ přestavby je další ideologickou fikcí. Výsledná frustrace působila jako rozbuška celospolečenské nespokojenosti, jakou KSČ neočekávala (Green, 2014).

V projevu ministryně školství ČSR Jany Synkové u př́iležitosti srazu učitelů v září 1989 se však již pojem glasnost objevuje pro zdůraznění, že „,se nacházíme ve zcela nové situaci“ (Účinné spojení školy s praxí: z vystoupení ministryně Jany Synkové, 1989, s. 3). 
Právě vlivem kolonizace přestavby konzervativním ÚV KSČ byla následně samotná reforma socialismu odmítnuta během sametové revoluce. To pomohlo ke ztotožnění se s mnohem radikálnějšími koncepty transformace (srov. Green, 2014) a mimo jiné přispělo k odmítnutí konceptu jednotné školy a socialistického školství jako celku.

\section{Nepřekročitelný rámec jednotné školy}

Nepřekročitelnost principu jednotné školy tvoří v oblasti vzdělávání pomyslnou paralelu s nepřekročitelností Poučení z krizovébo vývoje v širší rovině. Př́padné přestavbové mechanismy decentralizace a (pro oblast vzdělávání specifické) diferenciace jsou proto implementovány do koncepce, které zdánlivě odporují (srov. Jurčak, 2018). Ačkoli je koncept jednotné školy mnohem starší, oficiální texty se odkazují na programový dokument Dalši rozvoj československé výchovně-vzdélávací soustavy z roku 1976, který specifikoval politiku vzdělávání a vedl k legislativním změnám z roku 1978 a k prosazení školského zákona z roku 1984 (Vorlíček, 2004). Přestože snaha o unifikaci za účelem zajištění rovného přístupu ke kvalitnímu vzdělání všem žákům je paralelní k vývoji v západních zemích, v československém prostředí je (logicky) deklarována zejména inspirace Sovětským svazem (Politický a ekonomický rozbor k návrhu zásad zákona, 1983). Stěžejním znakem reforem bylo prodloužení povinné školní docházky na deset let a cíl, aby všichni, kteří ji splní, formálně získali stř̌edoškolské vzdělání. To by - minimálně ve formální rovině zvýšilo úroveň vzdělanosti celé populace.

Hodnocení implementace změn vzdělávacího systému jako spíše formální než skutečně funkční je vlastní nejen ostré porevoluční kritice normalizačního školství, ale i v pozdější reflexi z perspektivy soudobých dějin. Reforma sice deklarovala ambiciózní cíle, ve skutečnosti se však snažila řešit hlavně problémy neefektivního hospodářství. Zkrácení studia na základní škole o jeden rok $\mathrm{z}$ devíti na osm ročníků mělo vést $\mathrm{k}$ dřívějšímu př́chodu pracovních sil do praxe, a zvýšit tak produktivitu hospodářství. ${ }^{4}$

Konzervativním křídlem KSČ byl návrh na snížení počtu ročníků základní školy na osm spojován s návratem k Zákonu o školské soustavě a vzdělávání učitelů z roku 1953 implementovanému podle sovětského vzoru. Zkrácení školní docházky bylo tehdy taktéž obhajováno potřebami národního hospodářství - reforma však byla zpětně kritizovaná pro nesmyslnost, odbornou nepřipravenost a formálnost stejně jako zákon z roku 1984 (srov. Walterová, 2004). 
$\mathrm{V}$ podobném duchu, tedy ve snaze ušetřit a $\mathrm{v}$ potřebě reflektovat ekonomické náklady, se nesly i návrhy na reformy z roku 1989. Některé základní problémy spjaté s vzdělávacím procesem samotným však byly tak zjevné, že je již nebylo možno přehlížet. ${ }^{5}$

\section{K metodologii: dostupné zdroje a dostupnost zdrojů}

Doposud publikované odborné texty zaměřené na socialistické školství končí zpravidla zmínkou o 13. zasedání ÚV KSČ 30. března 1989, na kterém bylo projednáváno vzdělávání. Pozdější vývoj do listopadu 1989 není reflektován, přičemž výjimku tvoří práce zahraničních badatelu. Jistý odstup od tématu žrejmě vedl k zájmu o období, které by čeští autoři mohli přehlížet kvůli vlastní autochtonní zkušenosti (reformy nebyly v praxi aplikovány), ambivalentnímu vztahu k totalitnímu režimu a reflexi vyšší potřeby sledovat spíše vývoj po roce 1989 a dívat se do budoucna. Proto pouze německý historik pedagogiky Botho von Kopp a již zmíněný skotský historik David Alexander Green velmi stručně zmiňují i debaty o dílčích reformách školství mezi březnem a listopadem 1989.

Zatímco Von Kopp cituje výhradně periodický tisk, Green sleduje debaty o školství na místní úrovni, jelikož získal přístup $\mathrm{k}$ archivním materiálům lokální provenience (obvodní výbory KSČ v pražských čtvrtích, okresní výbory KSČ). Vedle toho pracoval i s materiály uloženými ve Slovenském národním archivu (SNA). Právě periodický tisk (Rudé právo a Učitelské noviny) a materiály ze SNA tvoří stěžejní pramennou základnu pro zpracování této studie. České zdroje reflektující vývoj na nejvyšší úrovni - fondy Ministerstva školství (dále též MŠ) ČSR, Úřradu vlády ČSR a zejména ÚV KSČ - byly v době realizace archivního výzkumu nezpracované, a tudíž nepř́stupné. Cenné informace vztažené i k českému prostředí však bylo možno získat v SNA díky úzké spolupráci i pravidelné výměně dokumentů české a slovenské vlády. Totéž platí i o fondech Komunistické strany Slovenska (KSS) která byla v rovině asymetrického uspořádání stranické hierarchie podřízena KSČ. Fondy Úřadu vlády slovenské republiky a KSS proto tvoří piliř citovaných zdrojů - studie tudíž pracuje s informacemi, které byly zaznamenány př́mo mocenskými institucemi pro jejich interní potřebu, př́padně předloženy široké veřejnosti pomocí sdělení zveřejněných $\mathrm{v}$ periodickém tisku.

Stejně tak zvýšení důrazu na zpracování prognóz ekonomického vývoje, projevující se v práci Prognostického ústavu ČSAV, mělo ve skutečnosti spíše podobu záchranných prací kolabujícího hospodářství než přípravy velkých koncepcí (Sommer, 2019; srov. Rákosník, 2012; Vorlíček, 2004). 


\section{Analýza československé výchovně-vzdělávací soustavy}

Implementace reformy školství z roku 1984 přinášela v kontextu neefektivního hospodářství řadu problémů. I z toho důvodu vzniklo v průběhu osmdesátých let několik analýz vzdělávacího systému (Walterová, 2004). Nejvíce viditelná byla analýza, která vznikla na základě usnesení ÚV KSČ z 26. února 1987 a měla být zpracována roku 1988 (Pracovní verze: Souhrnná zpráva k analýze, 1988, n. s. - úvodní slovo). Analýza československé výchovnè vadélávací soustavy (dále jen Analýza) zpracovávaná paralelně MŠ ČSR i MŠ SSR byla finalizována během jara 1988, přičemž měla následovat široká veřejná diskuze. Politická zpráva k Analýze byla zveřejněna v Učitelských novinách v červnu 1988 spolu s výzvou, aby jednotliví učitelé posílali svoje připomínky na MŠ ČSR a SSR. ${ }^{6}$ Lze si povšimnout, že veřejně dostupná verze Analýzy je přes obdobnou strukturu mnohem méně kritická než původní interní materiál z února 1988 určený pro vládu a KSČ. Do konce července 1988 bylo doručeno celkem 5764 připomínek v ČSR a 2183 v SSR od institucí i jednotlivců (Správa o analýze, 1988). Komentáře k Analýze se pravidelně objevovaly i v Učitelských novinách během léta a podzimu 1988 . $^{7}$ České ministerstvo školství však zpracovalo pouze cca 1000 připomínek, zatímco slovenské dokonce dvakrát tolik (Záznam z koordinační porady ministrů školství 13. září, 1988). Veřejná diskuze měla být zohledněna ve Zprávě o analýze československé vzdélávaci soustavy ze září 1988 (Správa o analýze, 1988). Finální materiál měl být předložen federální vládě ČSSR v prosinci $1988^{8}$ a tvořil jeden z podkladů pro 13. zasedání ÚV KSČ ke školství v březnu 1989.

Analýza byla k českému školství značně kritická a pojmenovala základní neduhy podobné těm, které byly reflektovány po roce 1989 - přebujelou byrokracii, zastaralé vybavení škol, nízké platy a klesající prestiž učitelů, přetěžování žáků učivem, zastaralé metody výuky apod. (Politická správa k Analýze, 1988; srov. Z Analýzy, 1988). Rozporuplná však byla taktéž reakce na analýzu ze strany politické moci, což svědčí o tom, že dokument nabourával hranice, které byly z ideového hlediska přijatelné. To naznačuje výtka,

\footnotetext{
6 Publikována byla zpráva v redukované verzi (neobsahuje mj. pasáž Věda a výzkum v resortě školstvi) (Z Analýzy, 1988; srov. Politická správa k analýze, 1988).

Připomínky k Analýze byly pravidelně publikovány v Učitelských novinách v rubrice Čtenáři k analýze - objevují se zde více či méně kritické podněty, zpravidla však vztažené zejména $\mathrm{k}$ praktickým záležitostem výuky. Publikovány byly příspěvky učitelů i širší veřejnosti - např́iklad dětský neurolog prof. Miloš Lehovský kritizuje př́lišný důraz na výkon a soutěživost při hodnocení dětí v tělesné výchově (Lehovský, 1988).

$8 \quad$ Vzhledem k zásadním rozdílům mezi verzemi MŠMT ČSR a MŠMT SSR bylo nakonec navrženo odložení projednání dokumentu na federální vládě (Záznam z koordinační porady ministrů školství 13. září, 1988).
} 
že z dokumentu vyplývá „resortní uzavřenost“. Tento pojem se objevuje jak v interních stranických a vládních materiálech (Záznam z koordinační porady ministrů školství 13. zárúi, 1988; Záznam zo zasedania Komisie ÚV KSS pre školstvo 28. února, 1989), tak v hodnocení Analýzy Pedagogickým ústavem ČSAV zpracovaném pro MŠMT ČSR a publikovaném v časopise Pedagogika (K materiálu o analýze, 1990). Obvinění z resortnosti se přitom stalo součástí ideologického jazyka a mělo značit, že se daná instituce nechová v souladu s politikou KSČ, což je př́ićinou problémů, na které upozorňuje. Odráží se tak tendence delegovat problémy na nižší úroveň mimo ústřední stranické struktury (srov. Pullman, 2011).

Analýze bylo dále vytýkáno řešení spíše procesních a organizačních záležitostí než samotného vzdělávání a nerozlišování významu podstatných a nepodstatných problémů. Dle kritiky nejsou brány v potaz „problémy ve světonázorové, mravní a ekologické výchově“ a Analýza redukuje reflexi osobnostního rozvoje na působení obsahu pedagogické práce ( $\mathrm{K}$ materiálu o analýze, 1990, s. 319). Zkrátka se Analýza drží př́iliš při zemi a nemá ambice řešit komplexnější cíle - tato reflexe však taktéž může odrážet disproporci mezi praktickými zkušenostmi s nefunkčním systémem a idejemi. Ministerstvo školství dostávalo podněty od pedagogické veřejnosti, vedení škol i pedagogických institucí na střední úrovni, a bylo tak konfrontováno s každodenními obtížemi, což se odrazilo během zpracovávání Analýzy. Perspektivy ústředních stranických orgánů i akademických kruhů pak volaly po hlubší koncepci a idejích. Ty se ale také lišily - zatímco KSČ žádala udržení vlastního ideologického konsenzu, vědečtí pracovníci ČSAV mohli z procesu zpracování Analýzy očekávat formulaci zásadních koncepcí vedoucích ke zlepšení kvality vzdělávání. Kritika zpracovaná pro ministerstvo školství odborníky z ČSAV pak musela tyto dvě ideové roviny (stranickou a odbornou) formálně skloubit $\mathrm{s}$ ideologickým konsenzem, o čemž svědčí užití pojmů jako resortnost.

Na Analýzu se odkazovalo plénum 13. zasedání ÚV KSČ v březnu 1989 stejně jako jemu předcházející zasedání ÚV KSS. Materiály zpracované Komisí pro školství, kulturu a umění ÚV KSS pro toto zasedání tvoří spolu se zápisy z diskuzí ministrů školství klíčový zdroj, ze kterého lze ilustrovat formu stranické kritiky školství i Analýzy. Podkladové materiály i zápisy z jednání reflektují jak Analýzu a problémy, které jsou v ní zdůrazněny, tak se k ní samé staví značně kriticky. Jednotlivé výtky, které se vedle interních stranických dokumentů objevují i v textech publikovaných $\mathrm{v}$ denním tisku, lze pomyslně rozdělit na perspektivu ideologickou, kritiku nefunkčního systému (tedy dvě roviny, mezi kterými balancovalo přijímání přestavby) a nakonec i na rovinu pedagogickou. Podívejme se na jednotlivé aspekty kritiky, které se objevily v rámci př́pravy, i následné reflexe 13. zasedání ÚV KSČ ke školství. 


\section{Ideologická rovina kritiky školství v krizi pozdního socialismu}

Jak jsme již naznačili, perspektiva čelních představitelů KSČ vycházela z nepřijatelnosti zpochybnění ideologického konsenzu. Odraz krize konce osmdesátých let a reflexe rizika oslabení vlastních pozic lze však vidět i v tom, že se objevuje motiv nepřijatelnosti zpochybnění vedoucí úlohy strany, který se odrážel v zesílené osvětě cílené na širší členskou základnu KSČ (Pullmann, 2011). Stejný motiv se objevuje i ve vztahu k výchově a vzdělávání. Podobné podněty se objevují nejen $\mathrm{v}$ pokynech pro komunisty po 13. sjezdu v Rudém právu, kde je (nepřekvapivě) prezentován úkol „účinněji politickými metodami uskutečňovat vedoucí úlohu strany“ (Usnesení 13. zasedání ÚV KSČ, 1989, s. 2), ale i v interních materiálech, ve kterých jsou zaznamenány výroky členů ÚV KSS, kteří měli pocit, že se od ideového základu upouští (což poukazuje na jejich odtržení od reality konce 80. let). Na jednání komisí pro školství ÚV KSS tak vedle kritiky praktických záležitostí zazněly názory, že je zpráva vypracovaná na základě Analýzy pro ÚV KSS málo politická, je v ní nutno „ostřeji zdůraznit otázky světonázorové výchovy, demonstrovat neústupnost od leninských principů, posílit kontrolu stranických organizací nad školstvím“ (Záznam zo zasadania Hlavnej pracovnej komisie, 1989, s. 2-5), „ukázat pozitivní výsledky po roce 1948 a podrobněji rozpracovat vedoucí úlohu strany" (Záznam zo zasadania Riadiacej komisie, 1989, s. 3-4).

Vedle základních ideologických mantinelů se objevuje motiv nezpochybnitelnosti konceptu jednotné školy, který se odrážel zejména v politických rozborech návrhů nových školských zákonů, ale je př́tomen i v politické zprávě k Analýze: kontrastuje přitom s debatou o vnitřní diferenciaci škol jako možnému kompromisu vedoucímu ke zlepšení kvality vzdělávání. Z interních diskuzí na vládní úrovni vyplývá nutnost balancovat oba motivy za účelem řešení akutních problémů a nenarušitelné ideologické koncepce. Místopředseda vlády ČSSR Matej Lúčan se ve svém projevu na poradě ministrů školství (Záznam z koordinační porady 13. září, 1988, s. 5) zamýšlel nad významem diferenciace:

Opakovanè se diskutuje o otážce jednotné školy. Ve škole jsou dèti podpriomèrné, prumèrné a nadprümèrné (talentované a nadané). Osnovy se dèlají spís pro primmèrné. $V$ dùsledku toho podpruimèrní nestači a nadprümèrní se nudí. Iden jednotné školy bychom mèli dř̌etet, ne ale zkostnatèle. Je tréba dát odpovéd" na to, jak. v jednotné šeole zabezpečit ruist talentovaných

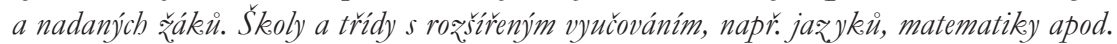
Je to návrat podle nékterých ke elité??

Čím dál těžší snaha ignorovat krizi souvisí jak s ideologickou, tak „praktickou“ rovinou narativu konce osmdesátých let. Jedná se o období spjaté s vlnami demonstrací během tzv. Palachova týdne v lednu 1989, peticí Několik vět a celkovým klesáním důvěry v socialismus (Rákosník et al., 2018). Reakce na 
aktuální situaci se v archivních pramenech i periodickém tisku sporadicky objevují. Ve vztahu ke školství lze zachytit zmínky o „negativním vlivu opozice, aktivitě antisocialistických sil “ (kterým však dle projevu ministryně školství na srazu učitelů nepodléhá většina žáků) i o hrozbě politických střetů v souvislosti s uplatňováním politiky glasnosti, díky níž se „protisocialistické síly“ budou pokoušet využít nezkušenosti mládeže (Účinné spojení školy s praxí: z vystoupení ministryně Synkové, 1989, s. 3). V souvislosti s besedou generálního tajemníka ÚV KSČ na sjezdu učitelů, který se konal na počátku září 1989, je v Rudém právu také konstatováno, že si mladí lidé do školy často přinášejí různé ,pokřivené názory - je pak na schopnosti pedagoga, aby na mládež patřičně působil“. Zde se objevuje i další přestavbový obrat - zvýšení důrazu na odpovědnost každého jednotlivce (Větší důvěru a samostatnost učiteli, 1989, s. 2).

Ačkoli jsou výrazněji kritické zejména interní materiály určené pro nejužší stranické vedení, ${ }^{9}$ pasivita, nezájem a nedůvěra rodičů je negativně hodnocena i v publikované verzi Analýzy (Z Analýzy, 1988). Denní tisk reflektuje i problémy s mládeží: narůstá vulgarita, zvyšuje se kriminalita i „alkoholová a nealkoholová toxikomanie“ (Větší důvěru a samostatnost učiteli, 1989). $\mathrm{Na}$ základě politické zprávy k Analýze je pak současná mládež sociálně nezralá, emocionálně chudá, hrubá a projevuje se celková krize hodnot i nedůvěra v socialismus (Z Analýzy, 1988). Nemenší kritika směřuje v interní zprávě KSS i na učitele - je zmiňována jejich psychická labilita, neefektivní, nekomplexní výchovné působení a výskyt fyzického trestání žáků (Informácie o podnetoch, 1989). Ve školách pak panují nedobré vztahy, ředitelé a vedení škol schopné pedagogy nepodporují, a naopak jim brání v kariérním postupu. ${ }^{10}$

Krize důvěry v socialismus se ostatně odráží i v klesajícím zájmu o školství, který je ostře kritizován v Rudém právu u př́ležitosti sjezdu učitelů (Nedělitelná odpovědnost za výchovu, 1989). V této souvislosti Analýza poukazu-

9 Obzvláště ostrý tón jmenující řadu aktuálních problémů školství se objevuje ve zprávě o stavu vzdělávací soustavy určené pro sjezd ÚV KSS ke školství v březnu 1989. Kritika byla z pohledu komise pro školství možná až př́liš ostrá, jak je patrno z citovaných připomínek: „Správa je dost’ poznačená Analýzou. Formulačne ju dat' do konštačnej podoby, smelšie vyjadrit' politikum, viac si v nej ,zafantazírovat'،"“ (Záznam zo zasadania Hlavnej pracovnej komísie, 1989, s. 3; srov. Správa na zasadanie Ústredného výboru KSS ku školstvu, 1989).

10 „Úroveň pripravenosti učitela a jeho vzt’ah k práci sa odráža v charaktere výchovnovzdelávacieho procesu (je v ňom často málo tvorivosti, motivácie k učeniu, priatel’ského vzt’ahu k žiakom, ai.). V pedagogických kolektívoch a u riaditelov sa prejavujú aj nekolegiálne a potlačovatel’ské tendencie voči schopným, vzdelaným, ambicióznym - a na vysokej škole náročným a zásadovým učitel’om.“ (Informácie o podnetoch, 1989, s. 29) 
je na snižování prestiže učitelů, ${ }^{11}$ jejichž práce a iniciativa je redukována centrálním řízením - přitom dle kritiky není předkládáno řešení, jak prestiž učitelů zvýšit (K materiálu o analýze, 1990). Jako odraz krize učitelského povolání i špatné ideově politické úrovně školství je reflektován klesající zájem učitelů o členství ve straně, což se odráží i na lokální úrovni - místní buňky KSČ v Praze jsou kritizovány, že se jim nepodařilo během roku zrekrutovat ve školách jediného člena KSČ (Green, 2014).

\section{Praktické problémy školství}

Pro veškeré interní i publikované dokumenty je však vlastní, že reflektují i problémy školství spjaté s upadající efektivitou centrálně plánovaného hospodářství. To se odráží v silně ideologizovaných debatách na úrovni KSČ, v hypernormalizovaném narativu periodického tisku a samozřejmě i v Analýze a materiálech na ní založených, kterým je přilišná kritičnost a nízká ideová úroveň vytýkána.

Jak již bylo naznačeno, zejména v materiálech provenience KSČ a veřejně publikovaných textech, je „vina“ za neefektivitu a krizi delegována na nižší úroveň řízení škol, lokální administrativu, místní stranické funkcionáře či jednotlivé učitele a zaměstnance školy, kteři jsou obviňování z nedůsledného plnění pokynů ÚV KSČ, a tím způsobují krizi systému. Problémy jsou způsobeny nedůsledným plněním rezolucí stranických orgánů (Správa na zasadanie Ústredného výboru KSS ku školstvu, 1989), čímž učitelé podrývají vedoucí úlohu strany (Green, 2014).

Na druhou stranu jsou kritizovány i reálné problémy školství: přetížení ředitelů kvůli nefunkčním službám a nutnosti suplovat stavebnictví (Záznam zo zasadania Hlavnej pracovnej komisie, 1989), špatná bytová situace, nekvalitní sociální a zdravotní zabezpečení, nízké platy učitelů, ${ }^{12}$ přebujelá korupce a protekcionismus rodičů (zejména v souvislosti s príiímacím ř́ízením) ) $^{13}$ a nedostupnost kvalitní elektroniky v souvislosti s programem elektronizace školství (Politická správa k Analýze, 1988).

11 „Spolu s přezíravým postojem části veřejnosti vưči učitelům a nedostatečnou hmotnou stimulací došlo fakticky k výraznému snížení prestiže učitelského a zejména vychovatelského povolání.“ (Pracovní verze: Souhrnná zpráva k analýze, 1988, s. 3).

12 Kritika nízkých platů učitelů je doplněna prohlášením ministerského předsedy Ladislava Adamce, že by se jejich ohodnocení mělo zvýšit (Větší důvěru a samostatnost učiteli, 1989).

13 „Mnohí rodičia sú presvedčení o tom, že na to, aby sa diet’a dostalo na strednú a vysokú školu, treba mat známosti, ,hrubé peňaženky‘. Aj ked’ priznávajú, že nie každé diet’a sa na školu dostane protekčne, považujú za potrebné sa ,poistit”“ a prijatie na školu ,vybavit'“"(Informácie o podnetoch, 1989, s. 12). 
Funkčnost vzdělávacího systému limituje i neefektivní, autoritativní a autokratický prŕístup školských odborů i ředitelů škol a malý podíl pedagogů ve vedení (Účinné spojení školy s praxí: z vystoupení ministra Kilára, 1989). Rovinu neefektivity personálního zabezpečení již bylo možno v souvislosti s přestavbou kritizovat, jelikož byla dávána za vinu nižší úrovni řízení či jednotlivcům a byla $v$ souladu s deklarovanou snahou o zefektivnění vedení škol a zvýšení ekonomické efektivity. Tento narativ pomáhal vytvářet zárodky porevolučního konsenzu, v němž důraz na efektivitu a decentralizaci zesílil. Opět se však v této souvislosti objevuje limitace vymezená ideologickým konsenzem: „Zároveň je nutné si uvědomit některé zásadní principy, z nichž naše školství vychází a od kterých nelze ustoupit - např. jednotná škola - a možnosti, které náš stát v souvislosti s hospodářským vývojem má.“ (Záznam z Koordinační porady ministrů školství 8. 2., 1988, s. 4)

„Odvážnější myšlenky mohly být prezentovány na odborné půdě ČSAV - na vědeckém kolegiu pedagogiky a psychologie 28. září 1988 hodnotícím na základě Analýzy aktuální otázky výchovně vzdělávací soustavy. Tam se objevil apel na hlubší promýšlení ekonomického aspektu vzdělávání a kritika separování vzdělávání od ekonomiky, přestože má zásadní vliv na hospodářský rozvoj. V této souvislosti jsou dokonce dávány za prúḱlad kapitalistické země, kde je vzdělání pevnou součástí př́ípravy teorií ekonomického růstu (Ke komplexnímu pohledu, 1989).

Se snahou delegovat odpovědnost za problémy školství na jednotlivce a instituce a s diskuzí o nutnosti zvýšit důraz na ekonomické mechanismy je spjato (a umožňuje ji) osvojení pojmů „odpovědnost“ a „socialistická podnikavost“ autoritativním jazykem nejpozdější fáze socialismu - tyto pojmy se mimo jiné objevují v usnesení ke školství po 13. zasedání KSČ..$^{14} \mathrm{Je}$ však třeba myslet na to, že osvojení přestavbového jazyka stranickými ideology souviselo spíše se snahou ovládnout jej za účelem uchování stávající mocenské struktury než s motivací k realizaci základních změn. Proměna narativu však mohla vytvářet naději mezi pedagogickou veřejností čelící aktuálním problémům vyplývajících nejen z neefektivity hospodářství a nefunkční administrativy, ale i z koncepce vzdělávání samotného.

Analýza a její reflexe na stranické, vládní i odborné úrovni totiž obsahuje také kritiku samotné pedagogické práce, která se v mnohém podobá diskuzím po roce 1989. Tato kritika je sice KSČ hodnocena jako resortní, avšak je dále reflektována a zohledňována - ve výsledku jsou zejména tyto praktické

14 „Zvyšovat spoluodpovědnost praxe za inovací obsahu vzdělávání a praktické př́pravy na povolání tak, aby umožňovala mladým lidem osvojovat si nové ekonomické myšlení, socialistickou podnikavost a principy chozrasčotu již v průběhu jejich př́pravy.“ (ÚV KSČ ukládá, 1989, s. 1). 
resortní nedostatky řešeny přijatými opatřeními. Mezi nejpalčivější praktické problémy patři přetěžování žáků př́liš velkým množstvím učiva, což má souvislost i s redukcí počtu ročníků základní školy (ZŠ) na osm. ${ }^{15}$ Objevuje se taktéž kritika velkého počtu žáků ve třídách a rozšířené praxe směnného vyučování (Pracovní verze: Souhrnná zpráva k analýze, 1988). Učitele pak trápí velké množství byrokracie, povinných schůzí, psaní posudků a školení, které brání v kvalitní př́pravě na výuku. ${ }^{16}$ Dále se budeme podrobněji zabývat jednotlivými návrhy, které měly reagovat na značnou kritiku československého vzdělávacího systému.

\section{Navrhovaná opatření, pokyny a proces př́ípravy novely školského zákona}

I přes rozpory v kritice z perspektivy jednotlivých aktérů (odborníků, funkcionářů, pedagogické veřejnosti) a mantinely, na které kritika narážela, se Analýza promítla do závěrů 13. zasedání KSČ. Odrazila se také v pokynech jednotlivým straníkům (tzn. zprostředkovaně vládě i pracovníkům ve školství) (ÚV KSČ ukládá, 1989) a v následných navrhovaných (a zčásti realizovaných) opatřeních. Mimo jiné v organizačních pokynech pro školní rok 1989-1990 (Pedagogicko-organizační opatření na školní rok 1989-1990, 1989) či v interním rozpracování 13. zasedání ministerstvem školství (Návrh rozpracování, 1989). Některá dílčí opatření pedagogického charakteru byla přitom řešena pomocí ministerských nařízení (a neodráží se v materiálech vládní provenience). Nejvýznamnějším bylo zřejmě zrušení známkování žáků prvních ročníků ZŠ, které bylo zavedeno již v roce 1988 (Pedagogicko-organizační opatření pro základní a střední školy a školská zařízení na školní rok 19881989, 1988; srov. Kopp, 1992).

Během roku 1989 probíhal proces přípravy novely zákona 29/1984 Sb., o soustavě základních a středních škol (školského zákona), a měl být vypracován dlouhodobý plán rozvoje školství do roku 1995 a 2010. Taktéž měl být do roku 1990 novelizován zákon o státní správě ve školství a zákon o vysokých

15 „[...] Orientácia školy a poznatky a náročnost' obsahu vyučovania spôsobuje, že deti vel'mi skoro strácajú záujem o učenie, prirodzenú zvedavost' a radost', s ktorou vstupovali do ZŠ. Ako je to možné, že škola dokáže za pár rokov odpudit’ deti a z učenia urobit' niečo nútené a zahanbujúce?“ (Informácie o podnetoch, 1989, s. 16; srov. Vorlíček, 2004).

16 „Např́iklad plynulou práci škol narušuje i častá účast učitelů na různých školeních, na plnění úkolů vyplývajících z různých funkcí, na poradách a akcích organizovaných nejen školskou správou, ale i společenskými organizacemi.“" (Účinné spojení školy s praxí: z vystoupení ministra Ludovíta Kilára, 1989, s. 3). 
školách. ${ }^{17}$ Novela školského zákona byla projednána na úrovni republikových vlád a prošla meziresortním připomínkovým řízením. Federální vláda ji měla projednat $\mathrm{v}$ listopadu 1989, předložení však bylo odloženo $\mathrm{z}$ důvodu potřeby hlubšího právního rozboru (Predkladacia správa, 1989).

Zákon zaváděl pouze dílčí úpravy, byl zamýšlen jako předstupeň zásadnějších reforem, které měly být připraveny do roku 1995 a jež měly vést ke vzniku „jednotné desetileté vnitřně diferenciované polytechnické školy“, která by zajišstovala celý rozsah povinné školní docházky (Predkladacia správa, 1989, s. 2). Události „velkých dějin“ však proces novelizace zákona předběhly a vedly $\mathrm{k}$ mnohem zásadnějším změnám. Na druhou stranu však jiné změny zbrzdily, protože zákon 29/1984 Sb. nakonec s dílčími úpravami platil až do roku 2004. Zmínky o př́pravě zákona se objevují v Rudém právu mimo jiné u př́ležitosti sjezdu učitelů - a v Učitelských novinách byl návrh zákona dokonce publikován (Návrh zásad novelizace zákona číslo 29/1984 Sb., 1989). Přesto doposud nebyla jeho př́iprava zpětně odborně reflektována. Pojd’me se nyní podívat na jednotlivá dílčí opatření, která vyplývala z pokynů po 13. zasedání KSČ a odrážela se i v podobě připravovaného zákona.

S opatrným prosazováním přestavby souvisí snahy o posílení odpovědnosti středních článkủ rrízení i ředitelů škol. Potřeba dosažení vyšší efektivity decentralizací a demokratizací (Předkládací zpráva, 1989) se odráží zejména v dílčích pokynech KSČ po 13. sjezdu - v konkrétních opatřeních se pak projevuje $\mathrm{v}$ přesunu kompetencí. Výrazněji se mělo delegování odpovědnosti na nižší články řízení odrazit v novelách zákonů o státní správě ve školství (ty však nebyly do listopadu 1989 projednány) (Předkládací zpráva, 1989; srov. Inventár, 1988-1992). Ačkoli je deklarováno posílení role ředitelů škol, objevují se i tendence ke zvýšení kompetencí funkcionárư na okresní úrovni v pokynu ,přehodnotit sít’ pedagogických a metodických pracovišst' v krajích a okresech se záměrem posílit okresní článek“ ř́żení (Návrh Rozpracování 13. zasedání ÚV KSČ, 1989, s. 5).

Přitom dle porevoluční reflexe vzdělávacího systému právě „stř̌ední stupeň - inspekce, státní pedagogické ústavy - způsoboval značnou neefektivitu vedení a fungování základních škol.

Pro učitele a učitelky strednich, základnich a mateřrskejch škol byl totalitni systém rǐrzení

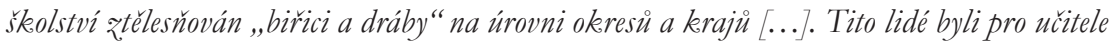
symbolem diktatury a blavni prekeážkou demokratickejch zmèn ve školství, a proto se prèdevšim snažili vymanit zjejich vlivu. Toho bylo možné dosábnout vètš̌ samostatností škol a zvýšním vlivu ministerstva školství. (Kalous, 1993, s. 236)

Bylo zamýšleno zavedení více stupňů VŠ studia (Návrh rozpracování 13. zasedání ÚV KSČ, 1989). 
Širší kontext pozdního socialismu ukazuje, že právě střední článek administrativy byl pro aplikaci jakýchkoli změn klíčový, jelikož odpovídal za implementaci pokynů z centra na místní úrovni (srov. Kabele, 2004). Funkcionáři na okresní úrovni mohli efektivně působit na aplikaci opatření, jelikož disponovali sociálním kapitálem a orientovali se v lokální situaci. Ztotožnění s přestavbou v podobě, jakou prosazoval ÚV KSČ, mezi funkcionáři na okresní úrovni tak bylo klíčové. Proto je měl narativ tlumočený „shora“ ujistit, že jejich mocenské pozice nejsou ohroženy (Pullmann, 2011).

To se mohlo odrážet i ve školství, kde se po roce 1989 situace zásadně změnila. Byla posílena odpovědnost obcí a struktura řízení škol měla dále podléhat př́mo MŠMT. Druhá rovina decentralizace - posílení odpovědnosti ředitelů škol - však kontinuálně přetrvala do období postsocialistické transformace.

Posílení odpovědnosti ředitelů škol se objevuje v řadě deklarací v periodickém tisku. Mimo jiné se má zvýšit jejich vliv na obsazování učitelských míst (Účinné spojení školy s praxí: z vystoupení ministra Kilára, 1989). Posílení role ředitelů souvisí s již zmíněným narativem důrazu na „odpovědnost“, který se v pokynech po 13. zasedání odráží ve vztahu k širší veřejnosti - vyšší podíl na chodu školy má mít také Sdružení rodičů a přátel školy (SRPŠ) a má se reformovat systém spolupráce mezi školami a organizacemi společenské praxe (Usnesení 13. zasedání ÚV KSČ, 1989; srov. Politická správa k Analýze, 1988). Tlak na vyšší odpovědnost je však delegován i na žáky v pokynu k přehodnocení systému sociálních výhod tak, aby se zvýšila jejich odpovědnost, ačkoli $\mathrm{k}$ tomuto kroku zjevně mohly vést i ekonomické problémy a potřeba hledat úspory. ${ }^{18}$

Ředitelé škol měli získat více kompetencí i ve vztahu k přijímacímu řízení na střední školy. To se mělo celkově zefektivnit a měla se odstranit administrativní zátěž na všech rovinách (Usnesení 13. zasedání ÚV KSČ, 1989). ${ }^{19}$ Učitelé základních škol na Slovensku pak neměli dle pokynů pro rok 19891990 zpracovávat osobní charakteristiku žáka, která měla být nahrazena osobním listem. V české verzi pokynů se toto opatření neobjevuje (Účinné spojení školy s praxí: z vystoupení ministra Kilára, 1989). Přijímací proces na střední a vysoké školy v období socialismu bývá obvykle spojován s vyso-

18 „Přehodnotit systém poskytování sociálních výhod žákům základních škol, středních škol a studentům vysokých škol tak, aby se zvýšila jejich aktivita a odpovědnost za plnění úkolů, úcta $\mathrm{k}$ celospolečenským hodnotám a $\mathrm{k}$ hospodárnému vynakládání prostř̌edků. [...] Termín: 1991.“ (Návrh rozpracování 13. zasedání ÚV KSČ, 1989, s. 9)

19 To se mělo odrazit i při posuzování přihlášek na odborné učiliště, kde již uchazeč nemusel disponovat souhlasem podniku, pro který se bude odborně připravovat (Návrh základních principů některých prováděcích předpisů, 1989). 
kým důrazem na spolehlivost uchazečů z třídního hlediska a zamezení př́stupu ke studiu dětem z politicky nepohodlných rodin. Tato možnost byla ostatně zakomponována $\mathrm{v}$ samotném školském zákoně, který obsahoval floskuli, že jsou studenti přijímáni na základě vágně definovaného „souladu s potřebami socialistické společnosti“ (Návrh: Zásady zákona o soustavě základních a středních škol, 1983, s. 44). V pozvánce na jednání mistrů školství v Brně z února 1988 se bez podrobnějšího komentáře objevuje zmínka o „nových kritériích uplatňování sociálně-tř́ídního hlediska v přijímání na stř̌ední a vysoké školy“ (Problémy předkládané na rozhodnutí na společné poradě vedení ministerstev školství, 1988, s. 2). Lze jen spekulovat, do jaké míry pak bylo skutečně od posuzování politické spolehlivosti uchazečů a jejich rodin upuštěno, či zda se jednalo pouze o kosmetické úpravy a formální deklarace.

Zefektivnění se však nemělo týkat jen přijímacích zkoušek, ale i vzdělávacího procesu. Učitelé i žáci měli být dle pokynů pro rok 1989-1990 oproštěni od vedlejších aktivit a povinností nad rámec vzdělávací činnosti, nadřízené složky měly omezit vyžadování písemných zpráv, ředitelé neměli vyžadovat písemné hodnocení vlastní práce pedagogů a celkově se měla racionalizovat schůzová činnost a omezit neefektivní jednání (Usnesení 13. zasedání ÚV KSČ, 1989).

Tento pokyn se odrazil i v návrhu novely školského zákona, která obsahovala pasáž, kdy veškerá účast studentů a žáků na „společensky odpovědné práci“ má být přesunuta mimo vyučování (Návrh zásad novely zákona, 1989). Toto opatření se stalo předmětem sporů $\mathrm{v}$ rámci meziresortního připomínkového řízení, jelikož s návrhem zásadně nesouhlasilo Ministerstvo zemědělství a výživy ČSR, totéž ministerstvo na federální úrovni stejně jako Svaz družstevních rolníků ČSR. Na základě kritiky bylo do návrhu zákona zapracováno, že ve výjimečných př́padech, pokud budou vyčerpány všechny ostatní možnosti a po omezenou dobu, může výjimku udělit vláda (Záznam z koordinační porady ministrů školství 16. srpna, 1989).

\section{Vnitřně diferencovaná jednotná škola jako cíl}

Základní a nejvíce diskutovanou záležitostí novely školského zákona byla snaha zefektivnit povinnou školní docházku. Ta reagovala jak na kritiku přetěžování učivem obsaženou v Analýze, tak i na snahu řešit aktuální problémy hospodářství. Vítězná alternativa (z dvou možných) umožňovala splnit povinnou desetiletou školní docházku výhradně v rámci základní školy.

Jednalo se o kompromis vzešlý na základě jednání ministrů školství i meziresortního připomínkového řízení. Původní dvě varianty navrhovaly bud' zavedení devátého ročníku, nebo zavedení jednoletého př́pravného 
kurzu, který měl pomoci připravit se ke studiu na střední škole těm, kteří nebyli přijati po absolvování závěrečného osmého ročníku ZŠ. Po absolvování jednoletého kurzu by dle této varianty mohli taktéž žáci požádat o předčasné ukončení povinné školní docházky, pokud dovršili věku 15 let.

Nakonec byla zvolena úspornější verze bez zavedení povinného devátého ročníku s tím, že byl nalezen kompromis $\mathrm{v}$ podobě zavedení jeho volitelné formy a následného jednoletého př́pravného kurzu, aby žáci nemuseli nastupovat na střední školu (SŠ) ani žádat o dřívější ukončení povinné školní docházky. Je zjevné, že jednou z klíčových motivací navrhovaných opatření byla snaha uspořit náklady na vzdělávání (Předkládací zpráva, 1989), jelikož vzdělávání na SŠ bylo finančně nákladnější než na základní škole. Proto se jevilo efektivnějším udržet žáky na ZŠ co nejdéle a zároveň neprodlužovat vzdělávací proces jako celek (k čemuž by vedlo plošné zavedení devátého ročníku). Toto opatření mělo být předstupněm ke zmíněné hlubší reformě školství.

Snaha nabídnout efektivnější model vzdělávání a nutnost balancovat s nepřekročitelností konceptu jednotné školy se objevuje v uvedení výše zmíněného pojmu „vnitřní diferenciace“ v definicích jednotlivých škol. Tato charakteristika mohla připravovat půdu pro rozšíření již zavedené praxe selekce žáků na ty výkonnější a na ty méně výkonné, která byla sice ideově nepřijatelná, avšak žádoucí z hlediska nedostatku kompetentních odborníků i přirozené ambice vysoce postavených rodičů poskytnout svým dětem co nejlepší vzdělání (srov. Záznam z koordinační porady ministrů školství 13. 9., 1988).

Další kapitolou související s finančním zabezpečením škol je možnost jejich samostatné výdělečné činnosti. Zatímco doposud mohly školy pouze za úplatu vykonávat se souhlasem místního národního výboru (MNV) činnost pro socialistické organizace a ponechat si výdělek (Zásady zákona ČNR, 1983). Podle návrhu nového zákona o státní správě ve školství měly školy, včetně základních, mít přímo možnost se souhlasem MNV samostatné výdělečné činnosti za účelem výdělku, což bylo navíc veřejně deklarováno v projevu ministryně školství na srazu učitelů (Účinné spojení školy s praxí: z vystoupení ministryně Synkové, 1989). V doporučeních k zabezpečení elektronizace školství v Analýze se navíc objevuje, že školy mají podíl této činnosti aktivně zvyšovat za účelem vyšších výdělků a modernizace vybavení školy (Správa o analýze, 1988).

\section{Prognózy střednědobého a dlouhodobého vývoje}

Řada pokynů se nesla pouze $\mathrm{v}$ obecných deklaracích, které bylo v plánu následně přepracovat do konkrétních opatření. Stěžejním dokumentem na 
úrovni České socialistické republiky se měl stát Komplexníprogram péče o mladou generaci ČSR s výhledem do roku 1995 a do roku 2010, který měl být předložen vládě ČSR v 1. pololetí roku 1989. Dlouhodobá koncepce pro tř̌etí tisíciletí počítající se zřízením desetileté všeobecné polytechnické školy pak měla být zpracována do roku 1993 (Návrh rozpracování 13. zasedání ÚV KSČ, 1989). Přímo v pokynech po 13. zasedání ÚV KSČ však byly zakomponovány i dílčí cíle, které měly reagovat na některá neuvážená rozhodnutí z minulých dob. Např́iklad měla být přehodnocena strategie rušení malotřídních škol (Usnesení 13. zasedání ÚV KSČ, 1989; srov. Trnková, 2006), což je téma, které rezonovalo i v období po sametové revoluci, a řada tzv. malotř́́dek byla ve skutečnosti nakonec obnovena (Zprávy o národní politice ve vzdělávání, 1996).

Nutnost balancovat mezi ideologickým konsenzem a potřebou řešit neefektivitu systému se logicky odrazila i v dlouhodobých plánech, které avizovaly přepracování materiálů o marxismu-leninismu $\mathrm{v}$ duchu přestavby a prohlubování socialistické demokracie. Události 17. listopadu však přišly dř́ive než se jakékoli prognózy, byt' jen krátkodobé, stačily naplnit. Ostatně přišly ještě dříve, než bylo možno vyhodnotit pokyny k organizaci školního roku 1989_ 1990. Sametová revoluce pak přinesla zásadní obrat v diskuzi o vzdělávací politice. $\mathrm{V}$ poslední části studie se proto zaměříme na možné kontinuity v debatě před a po roce 1989.

\section{Paralely s transformací}

Jak jsme již naznačili, neoliberální představy nejen o školství raných devadesátých let se od těch přestavbových značně lišilly, přestože lze nalézt celou řadu paralel. Sledování kontinuit mezi pozdním socialismem a postsocialistickou transformací je rozvinutější v zemích s výraznějším podílem vyjednávání mezi „starou“ a „novou“ mocí, jako jsou Polsko a Mad’arsko (Kopeček, 2019). V československé perspektivě převládá obraz živelných změn „zespoda“, které stavěly na zásadním odmítnutí socialistického školství jako celku. Kritika mohla jít mnohem dál a nebyla svázaná cenzurou, avšak jednotlivá dílčí témata zůstala podobná. Zatímco před rokem 1989 limitovala kritiku ideologie, po roce 1989 byla hlavní brzdou prosazování změn nekoncepčnost. Faktory, které ovlivňovaly každodenní život škol na denní bázi - zastaralé vybavení, nekompetence řídících orgánů, neefektivní komunikace - však přetrvávaly.

Náznaky kontinuit mezi přestavbovým a transformačním narativem lze však hledat i v oblastech, které bývají spojovány spíše se zásadním obratem $\mathrm{v}$ představách o vzdělávání. Třeba reflexe potřeby diferenciace za účelem zefektivnění vzdělávání se objevuje i před rokem 1989, ačkoli „pouze“ v rovině možné „vnitřní diferenciace“ nepřek ročitelného modelu jednotné školy. 
Transformace pak otevřela mnohem širší perspektivy vedoucí k odmítnutí modelu jednotné školy jako celku. Zohlednění rozdílů mezi žáky je vnímáno jako přirozené (Bečvář \& Veselý, 1993) a školy se od sebe měly lišit podle prestiže a náročnosti, přčcemž měl být přijatelný i přirozený vliv ekonomického kapitálu rodin na dostupnost vzdělání ${ }^{20}$ a mechanické rovnostářství bylo vnímáno jako škodlivé (Tým pedagogické fakulty UK, 1992). Je však nutno podotknout, že podobné názory tvořily pouze jeden z pólů a byly i soudobými odborníky kritizovány.

Výraznější kontinuity lze vidět v podobě kritiky školství: stejně jako před rokem 1989 se i hodnocení z 90. let neobejde bez zmínek o př́lišném důrazu na encyklopedické znalosti žáků, neprúiznivých výsledcích srovnávacích testů (Zprávy o národní politice ve vzdělávání, 1996), nízké míře demokratičnosti i individuálního př́istupu ve výuce (Perry, 2005), kontinuálně druhořadé prioritě financování škol (Kotásek, 1993) či přetrvávající tendenci k direktivnímu řízení (Zprávy o národní politice, 1996). Tyto problémy byly přirozeně vnímány jako „přežitky“ socialismu.

Ačkoli kritika praktických záležitostí života škol byla podobná, představám o podobě vzdělávání jako celku dominoval zásadní obrat spjatý s odmítnutím socialistického školství jako celku včetně jeho reforem. Ostré texty pochází zejména z počátku devadesátých let. Ilustrativním příkladem může být pohled socioložky Marie Čermákové publikovaný v časopise Pedagogika v roce 1991, která v něm např́klad tvrdí, že reformy nebyly vědecky podložené, idea jednotné školy byla založená zejména na stalinských tendencích podřídit vše státní kontrole, podfinancování aplikovaly totalitní režimy cíleně, aby společnost včetně vzdělávacích institucí udržovaly v materiálním nedostatku a lidem nezbývala energie na touhu po získání i poskytování kvalitního vzdělání (Čermáková, 1991).

Pro debaty o transformaci školství byl symptomatický odpor k plánování jako reminiscenci státního socialismu - to vedlo k utopistickým vizím o přirozené samoregulaci (NEMES, 1991). Na druhou stranu se však objevují varování před unáhleným návratem ke školství před rokem 1948 - je totiž nutno reflektovat vývoj a sledovat procesy na Západě (Čerych, 1995). Podobné hlasy logicky sílí spolu s postupující deziluzí z živelné a nekoncepční transformace (srov. Bečvář \& Veselý, 1993; Čermáková, 1991; Kotásek, 1993).

20 „Demokracie, má-li byt životná, musí respektovat fakt nejrůznější nerovnosti lidi, např. fyzické, intelektuální, psychické, ale také ekonomické a sociální. V demokratickém statě je třeba dbát, aby byla plně respektovaná rovnost před zákonem a vytvářena co možná stejná př́iležitost všem s vědomím, že plně životni rovnosti dosáhnouti nelze.“ (Tým pedagogické fakulty UK, 1992, s. 10). 
Velmi ojedinělé pozitivní hodnocení konceptu jednotné školy jako progresivního a inovativního můžeme zachytit $\mathrm{v}$ odborné debatě na Slovensku, které se celkově vyznačovalo více opatrným přijímáním přechodu k tržnímu hospodářství i pozitivnější reflexí období tzv. normalizace (Kosová, 2011).

Z předrevolučního návrhu zákona bylo nakonec realizováno zavedení povinného devátého ročníku základních škol. Decentralizace pokročila mnohem dál a vedla až ke vzniku právní subjektivity škol a přesunu řízení pod resortní správu v podobě školských úradů podřízených MŠMT, zatímco za socialismu bylo školství součástí agendy ONV a KNV. Dalším skutečně realizovaným podnětem z přestavbové debaty bylo obnovení malotř́idek, $\mathrm{k}$ němuž pomohl vládní program rozvoje malých obcí (41\% počtu škol a podíl 8 \% žáků v roce 1996) (Čerych, 1999).

\section{Místo závěru - fungoval by reformovaný systém jednotné školy?}

Vzdělávací systém v Československu narážel v období pozdního socialismu na limity nepřekročitelnosti ideologického konsenzu, které v období transformace vystřídal odpor k plánování vedoucí k odmítání jakýchkoli dlouhodobých koncepcí. Reformy se tak děly „zespoda“, živelně a mnohdy nekoncepčně, což přispělo k přetrvávání zásadních potíží vzdělávacího systému, které nebylo možno vyřešit ze dne na den a jež byly spjaty s hluboce zakořeněnými problémy československé společnosti: s nedostatkem kompetentních elit, absencí zkušeností a manažerských dovedností, tradicí neefektivního a přebyrokratizovaného státního aparátu, ale i nízkou pracovní morálkou a nedostatkem materiálního vybavení. Tato kombinace logicky nemohla pomáhat praktické aplikaci reforem, navíc limitovaných ideologií - at’ už socialistickou nebo neoliberální. Je jen symptomatické, že vlivem procesu přestavby stavěl ideový koncept nejpozdějši fáze socialismu i rané fáze postsocialistické transformace na podobných pojmech - demokratizaci, diferenciaci a odpovědnosti.

Je možno položit si hypotetickou otázku, jak by podobu vzdělávacího systému ovlivnilo aplikování zamýšlených opatření spjatých se snahou o decentralizaci v kontextu přestavby. Možným alternativním vývojem se ve své studii zabýval Jiř́ Suk, který konstatuje, že tendence realizovat „třetí cestu“, tzn. spíše opatrné reformy ve formě demokratického socialismu, byly na stole zhruba až do 5. prosince 1989. Tedy dokud nebyl jako lídr opozice definitivně zvolen Václav Havel (který ostatně taktéž nepatřil mezi propagátory ostrého přechodu $\mathrm{k}$ neregulovanému tržnímu hospodářství). Do té doby se předpokládalo, že se hybnou silou reforem a klíčovými představiteli ve vyjednávání podmínek předání moci stanou spíše reformní komunisté vyloučení po roce 1968 ze strany, sdružení v hnutí Obroda (Suk, 2009). 
V takovém případě je možné, že by byly skutečně dokonány či jen mírně upraveny reformy plánované po zpracování Analýzy.

Prosazení plánovaných reforem by zřejmě naráželo na ty samé problémy, na kterých selhávalo i aplikování koncepce jednotné školy - na nekoncepčnost a absenci zkušeností. Lze totiž sledovat paralely s mad’arským vývojem, ve kterém bylo přikročeno k reformě školství již v roce 1985. Decentralizace vedla k rozpadu a ještě nižší funkčnosti systému - stát dal školám odpovědnost bez jasné koncepce. Učitelé zažili ve druhé polovině 80. let období nejistoty, získali pocit, že je stát nechal napospas, a volali po návratu ke starým pořádkům a tradiční formě centrálního dohledu (Halász, 1993). Nelze očekávat, že by tomu bylo v Československu jinak. Jak konstatuje Pullmann (2011), i ředitelům státních podniků chyběla kompetence krizového řízení, což vedlo po aplikaci reforem k ještě vyšší neefektivitě. Lidé, kteří byli zvyklí poslouchat pokyny „,shora“ najednou dostali moc, se kterou neuměli zacházet.

Nešlo tedy ani tak o dílčí koncepci, ale o celkové principy fungování systému, kdy úspěch závisel nejen na pokynech „,z centra“, ale i na schopnostech jejich koordinace a zabezpečení na lokální úrovni. I na tom selhávalo prosazování jed notné školy, která ostatně nebyla ojedinělým vynálezem státního socialismu - ten ji pouze nedokázal efektivně uplatnit. Lze sledovat paralely s prosazováním podobných myšlenek dříve (myšlenka jednotné školy má kořeny již ve 20. letech 20. století) (Rákosník \& Tomeš, 2012) i jinde (koncepce jednotné školy se prosazovaly v 60. a 70. letech na Západě) (Mitter, 1991). Unifikační tendence se navíc po zásadně decentralizačním období 90. let začaly prosazovat i v České republice např́íklad ve snaze sjednotit a standardizovat zkoušky jako milníky průchodu vzdělávacím systémem. V té souvislosti sílila i kritika v 90. letech zř́izených víceletých gymnázií a př́liš brzké separace talentovaných žáků od těch méně nadaných (které může mít celospolečenské dopady).

Je tedy zjevné, že nejde o samotnou koncepci, ale o možnosti její efektivní aplikace. Prosazení idejí jednotné školy bylo v pozdně socialistickém Československu značně limitováno vinou neefektivity systému. Výsledkem tak byla spíše fikce jednotné školy svázaná ideologickým konsenzem. Silná ideologizace normalizačního i pozdějšího přestavbového jazyka pak vedla k zásadnímu odmítnutí systému jednotné školy jako celku v období transformace.

Stejně jako u přestavby a různých třetích cest přechodu mezi socialismem a tržním hospodářstvím vedla ideologizace konceptu jednotné školy v kontrastu s neefektivní aplikací tohoto modelu k inflaci samotné podstaty myšlenek, na kterých stála - tj. snaze poskytnout rovné podmínky pro vzdělání všem bez ohledu na jejich původ - a k přehlížení pozitivních příkladů aplikace podobných reforem, např́iklad ve Skandinávii. Stejně jako v jiných oblastech života společnosti tak začaly být hledány inspirace spíše v anglo- 
saském světě vyznačujícím se mnohem výraznější decentralizací - tedy systémem, který se od československé vzdělávací soustavy značně lišill.

Reálná aplikace jakýchkoli opatření nesouvisí pouze s ideologií a fungováním státní moci, ale i se schopností tyto koncepce přijímat na lokální úrovni a ochotě je aplikovat $\mathrm{v}$ praxi. Jakékoli centrálně iniciované změny se na lokální úrovni logicky odrazí později a úspěch vzdělávací politiky souvisí i s kompetencemi jednotlivců, mezilidskými vztahy, kvalitou spolupráce, důvěrou a velmi výrazně taktéž s kvalitou samotného školského systému. I kvůli tomuto uzavřenému kruhu je důležité sledovat aplikaci reforem v minulosti a brát $\mathrm{v}$ potaz faktory, které ji ovlivnuují. Plány na reformy z nejpozdějšího období socialismu sice tvoří pouze epizodický výsek procesu vývoje vzdělávacího systému, jejich studium však poukazuje na význam promýšlení podoby vzdělávání $\mathrm{v}$ širším celospolečenském kontextu.

\section{Poděkování}

Studie vznikla v rámci řešení projektu Post-socialistická transformace základnich škol - procesy, príběby, dilemata financovaného Grantovou agenturou Č̉eské republiky (č. projektu 20-11275S). Autoři děkují za poskytnutou podporu.

\section{Literatura}

Bečvář, J., \& Veselý, J. (1993). Perspektivy českého školství. Pedagogika, 43(2), 133-136.

Berend, I. T. (2009). From the Soviet Bloc to the European Union: The economic and social transformation of Central and Eastern Europe since 1973. Cambridge University Press. https://doi.org/10.1017/ CBO9780511806995

Čermáková, M. (1991). Formování totalitního školství v poválečném Československu. Pedagogika, 41(3), 323-333.

Čerych, L. (1995). Educational reforms in Central and Eastern Europe. European Journal of Education, 30(4), 423-435. https://doi.org/10.2307/1503515

Čerych, L. (1999). General report on the symposium „Educational reforms in Central and Eastern Europe: Processes and outcomes“. European Education, 31(2), 5-38. https://doi. org/10.2753/EUE1056-493431025

Green, D. A. (2014). The Czzechoslovak Communist Party's Revolution, 1986-1990 [Disertační práce]. The University of Strathclyde library: Digital collections. http://digitool.lib.strath.ac. $\mathrm{uk} / \mathrm{R} /$ ?func $=$ dbin-jump-full\&object_id $=24879$

Halász, G. (1993). Politika autonomie škol a reformy řízení vzdělávání a výchovy. Změny v Mad’arsku v perspektivách východní Evropy. Pedagogika, 43(1), 27-32.

Houda, P. (2019). Normalizaćní festival: socialistické paradoxy a postsocialistické korekce. Karolinum.

Informácie o podnetoch z. besied členov ÚV KSS a pracovnikov oddelenia škeolstva a vedy ÚV KSS spredstavitelmi spoločenskej praxe k zasadaniu ÚV KSS ku školstvu. (1989). Zasedání ze dne 28. 
2 1989, fond Komisie ÚV KSS pre školstvo, kultúru a umenie 1988-1989 (kr. 1, sg. 2). Slovenský národný archiv.

Inventár 1988-1992. Legislativní rada vlády, fond Úradu vlády SSR 1988-1992. Slovenský národný archiv.

Jurčak, A. (2018). Bylo to na věčné časy, dokud to neskončilo: posledni sovètská generace. Karolinum.

K materiálu o analýze československé výchovně vzdělávací soustavy. (1990). Pedagogika, 40(3), 315-322.

Kabele, J. (2004). Filipovští komunisté na konci dvacátého století. In J. Kandert (Ed.), Jihomoravský venkov po socialismu: Filipovsko na konci devadesátých let 20. století: (Informatoria katedry sociologie - Filipov III) (s. 7-19). Matfyzpress.

Kalous, J. (1993). Školská politika v České republice po roce 1989. Pedagogika, 43(3), 235-239.

Ke komplexnímu pohledu na problematiku výchovně vzdělávací soustavy. (1989). Pedagogika, 39(3), 270-305.

Kopeček, M. (2019). Expertní kořeny postsocialismu: výzkumné perspektivy a metodologické nástroje. In M. Kopeček (Ed.). Architekti dloubé żěny: expertni kořeny postsocialismu $v$ Ceskoslovensku (s. 9-40). Argo.

Kopp, B. (1992). The Eastern European revolution and education in Czechoslovakia. Comparative Education Review, 36(1), 101-113. https://doi.org/10.1086/447084

Kosová, B., \& Porubský, Š. (2011). Slovenská cesta transformácie edukačného systému po roku 1989 na príklade primárneho vzdelávania a prípravy jeho učitelov. Pedagogická orientace, 21(1), 35-50.

Kotásek, J. (1993). Vize výchovy v postsocialistické éře. Pedagogika, 43(1), 9-19.

Lehovský, M. (1988). Známka z tělocviku? Ucítelské noviny, 4(28).

McDermott, K. (2015). Communist Czechoslovakia, 1945-89: A political and social history. Macmillan Education.

Mitter, W. (1991). School reforms in international perspective. Trends and problems. Pedagogika, 41(1), 7-23.

Moree, D. (2013). Učitelé na vlnách transformace: kultura školy préd rokem 1989 a po nèm. Karolinum.

Návrh rozpracováni 13. zasedáni ústréedního výboru Komunistické strany Ceskoslovenska ministerstvem školství, mládeže a tělovýchovy ČSR. (1989). 176. zasedání 5. 9. 1989, legislativní rada vlády, fond Úradu vlády SSR 1988-1992 (kr. 26, sg. 14). Slovenský národný archiv.

Návrh základnich principů některých provádécích predpisů. (1989). Zasedání ze dne 13. 10. 1989, fond Komisie ÚV KSS pre školstvo, kultúru a umenie 1988-1989 (Kr. 1, sg. 4). Slovenský národný archiv.

Návrh zásad novelizace zákona číslo 29/1984 Sb., o soustavě základních a středních škol. (1989). Uciitelské noviny, (19), 6.

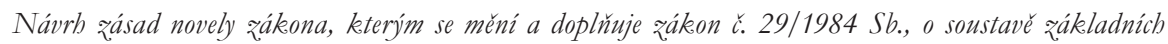
a středních škool. (1989). 176. zasedání 5. 9. 1989, legislativní rada vlády, fond Úradu vlády SSR 1988-1992 (kr. 26, sg. 14). Slovenský národný archiv.

Návrb: Zásady zákona o soustavě qákladnich a střednich škol /školský zákon/. (1983). Porada ze dne 21.4.1983, pracovná porada funkcionárov ministerstva školstva ČSR a SSR, fond Úradu vlády SSR 1981-1987 (kr. 4, sg. 39). Slovenský národný archiv.

Nedělitelná odpovědnost za výchovu. (1989, 12. září). Rudé právo, 1.

NEMES. (1991). Svoboda ve vądèlání a česká škola. Náurb projektu zmèny vąuelávacího systému v České republice. Nemes: Nezávislá mezioborová skupina. 
Pedagogicko-organizační opatření pro základní a stř̌ední školy a školská zařízení na školní rok 1988-1989. (1988, květen). Učitelské noviny: príloha Obzor.

Pedagogicko-organizační opatření pro základní a stř̌ední školy a školská zařízení na školní rok 1989-1990. (1989, červen). Učitelské noviny: príloha Obzor.

Perry, L. B. (2005). The seeing and the seen: Contrasting perspectives of post-communist Czech schooling. Compare: A Journal of Comparative and International Education, 35(3), 265-283. https://doi.org/10.1080/03057920500212548

Politická správa ke analýze československej výchovno vzdelávacej sústavy: 2. verz̨ia: Január 1988. (1988). Porada ze dne 8. 2. 1988, koordinační porady u místopředsedy vlády Lúčana, fond Úradu vlády SSR 1988-1992 (kr. 4, sg. 363). Slovenský národný archiv.

Politický a ekonomický rozbor k návrbu zásad qákona o soustavé qákladnich a strednich škol /školský zákon/. (1983). Porada ze dne 21. 4. 1983, pracovní porady vedoucích funkcionářů MŠMT ČSR a SSR, fond Úradu vlády SSR 1981-1987 (kr. 4, sg. 36). Slovenský národný archiv.

Pracovni verze: Soubrnná zpráva ke analýze čs. výchovně-vzdělávaci soustavy: 24. srpen 1988. (1988). Porada ze dne 13. 9. 1988, koordinační porady u místopředsedy vlády Lúčana, fond Úradu vlády SSR 1988-1992 (kr. 4, sg. 364). Slovenský národný archiv.

Predkladacia správa a そhodnotenie med zirezortného pripomienkovébo konania: náurh qásad novely zákona c. 29/1984 Zb. o sústave základných a sterdných škồl. (1989). 176. zasedání 5. 9. 1989, legislativní rada vlády, fond Úradu vlády SSR 1988-1992 (kr. 26, sg. 14). Slovenský národný arcbív.

Problémy prèdkládané na rozhodnutí na společné poradě vedeni obou ministerstev školství v únoru 1988 v Brně. (1988). Porada 8. 2. 1988, koordinační porady u místopředsedy vlády ČSSR Lúčana, fond Úřadu vlády SSR 1988-1992 (kr. 4, sg. 363). Slovenský národný archív.

Průcha, J. (Ed.). (2009). Pedagogická encyklopedie. Portál.

Průcha, J., Walterová, E., \& Mareš, J. (2009). Pedagogický slouník. Portál.

Predkládaci zpráva ke návrbu zásad zákona, kterým se mèni a doplňuje zákon č. 29/1984 Sb., o soustavě základních a strednich škol (školský zákon). (1989). Zasedání ze dne 13. 10. 1989, fond Komísie ÚV KSS pre školstvo, kultúru a umenie 1988-1989 (Kr. 1, sg. 4). Slovenský národný archiv.

Pullmann, M. (2011). Konec experimentu:prestavba a pád komunismuv Československu. Scriptorium.

Rákosník, J., \& Tomeš, I. (2012). Sociálni stát v Ceskoslovensku: právně-institucionální vývoj v letech 1918-1992. Auditorium.

Rákosník, J., Spurný, M., \& Štaif, J. (2018). Milníky moderních českých dějin: krize konsenzu a legitimity $v$ letech 1848-1989. Argo.

Rýdl, K. (2006). Historický vývoj českého vzdělávání do roku 1989. In J. Kalous \& A. Veselý (Eds.), Vz délávaci politika Ceské republiky v globálním kontextu (s. 7-22). Karolinum.

Rychlík, J. (2020). Ceskoslovensko v obdobi socialismu: 1945-1989. Vyšehrad.

Sommer, V. (2019). Ŕidit socialismus jako firmu: technokratické vládnutív Československu, 1956-1989. Ústav pro soudobé dějiny AV ČR.

Správa na zasadanie Ústrednébo výboru KSS ku školstvu. (1989). Zasedání ze dne 28. 2. 1989, fond Komisie ÚV KSS pre školstvo, kultúru a umenie 1988-1989 (kr. 1, sg. 2). Slovenský národný archiv.

Správa o analýze československej výchovno-vzdelávacej sústavy. (1988). Komisia vlády SSR pre koordináciu realizácie dlhodobého programu rozvoja československej výchovno-vzdelávacej sústavy + zvyšovanie kvalifikačnej úrovne + prestavba hospodárskeho mechanizmu, fond Úradu vlády SSR 1988-1992 (kr. 2, sg. 162). Slovenský národný archiv.

Suk, J. (2009). Zlom mezi „totalitou“ a „demokraciî“: Československý rok 1989 v alternativách. Soudobé déjiny, 16(4), 557-604. 
Trnková, K. (2006). Vývoj malotřídních škol v druhé polovině 20. století. Sborník prací Filosofické fakulty brnènské university. C, Řada historická, 54(11), 133-144.

Tým pedagogické fakulty UK. (1992). Rozvaha o školství a vzdělanosti a jejich dalším vývoji v českých zemích. Pedagogika, 42(1), 5-18.

Účinné spojení školy s praxí neodkladným úkolem: z vystoupení ministryně Jany Synkové. (1989). Rudé právo, 3.

Účinné spojení školy s praxí neodkladným úkolem: z vystoupení ministra L’udovíta Kilára. (1989, 11. záríi). Rudé právo, 3.

Usnesení 13. zasedání ÚV KSČ o úkolech československého školství v podmínkách přestavby společnosti. (1989, 1. dubna). Rudé právo, 2.

ÚV KSČ ukládá. (1989, 1. dubna). Rudé právo, 1.

Větší důvěru a samostatnost učiteli (1989, 9. září). Rudé právo, 2.

Vorlíček, Ch. (2004). České školství v letech 1945-2000. In E. Walterová (Ed.), Česká pedagogika: Promény a výzvy: Sborník k životnimu jubileu profesora Jiř́bo Kotáskea (s. 119-176). Pedagogická fakulta Univerzity Karlovy.

Walterová, E. (2004). Úloha školy v rozuoji vądèlanosti. 1. díl. Paido.

Z Analýzy československé výchovně vzdělávací soustavy. (1988, červen). Učitelské noviny: príloha Obzor).

Zákon č. 95/1948 Sb., zákon o základni úpravě jednotného školství (školský zákon). (1948). https:// www.psp.cz/sqw/sbirka.sqw?cz=95\&r=1948

Zásady zákona ČNR, kterým se mèni a doplñuje zákon ČNR o státní správě ve školství a zákon ČNR o školských zarízenich. (1983). Porada ze dne 21.4.1983, pracovná porada funkcionárov ministerstva školstva ČSR a SSR, fond Úradu vlády SSR 1981-1987, (kr. 4, sg. 39). Slovenský národný archív.

Záznam z. Koordinačni porady ministrư škoolství mládeže a tělovýchovy u 1. mistoprédsedy vlády ČSSR s. M. Lúčana konané dne 8. února 1988. (1988). Koordinační porady u místopředsedy vlády ČSSR Lúčana, fond Úradu vlády SSR 1988-1992 (kr. 4, sg. 363). Slovenský národný archiv.

Záznam z koordinačni porady ministrù školství, mládeže a tělovýchovy u mistopredsedy vlády ČSSR s. Mateje Lúčana konané dne 13. zárí 1988. (1988). Koordinační porady u místopředsedy vlády Lúčana, fond Úradu vlády SSR 1988-1992 (kr. 4, sg. 364). Slovenský národný archiv.

Záznam z koordinační porady ministrư školství mládežze a tělovýchovy u 1. mistopréedsedy vlády CSSR s. M. Lúčana konané dne 16. srpna 1989. (1989). 176. zasedání 5. 9. 1989, legislativní rada vlády, fond Úradu vlády SSR 1988-1992 (kr. 26, sg. 14). Slovenský národný arcbiv.

Záznam zo rasadania Hlavnej pracovnej komisie pre prípravu zasadania ÚV KSS ke škoolstvu - 15. 2. 1989 ÚV KSS. (1989). Fond Komisie ÚV KSS pre školstvo, kultúru a umenie 1988-1989 (Kr. 1, sg. 2). Slovenský národný archiv.

Záznam zo zasadania Komisie ÚV KSS pre školstvo, kultúru a umenie (28. 2. 1989 na ÚV KSS). (1989). Fond Komisie ÚV KSS pre školstvo, kultúru a umenie 1988-1989. (kr. 1, sg. 2). Slovenský národný archiv.

Záznam zo zasadania Riadiacej komisie pre prípravu zasadania ÚV KSS ku školstvu, 16. 2. 1989. (1989). Fond Komísie ÚV KSS pre školstvo, kultúru a umenie 1988-1989 (kr. 1, sg. 2). Slovenský národný archiv.

Zounek, J., Šimáně, M., \& Knotová, D. (2017). Normálni život v nenormálni době: Základni školy a jejich učitelé (nejen) v obdobi normalizace. Wolters Kluwer.

Zprávy o národni politice ve vadęláváni (1996). Ústav pro informace ve vzdělávání. 


\section{Kontakt na autory}

\section{Oto Polouček}

Ústav pedagogických věd, Filozofická fakulta, Masarykova univerzita

E-mail: poloucek@phil.muni.cz

Jiří Zounek

Ústav pedagogických věd, Filozofická fakulta, Masarykova univerzita

E-mail: zounek@phil.muni.cz

\section{Corresponding Authors}

Oto Polouček

Department of Educational Sciences, Faculty of Arts, Masaryk University

E-mail:poloucek@phil.muni.cz

Jiří Zounek

Department of Educational Sciences, Faculty of Arts, Masaryk University E-mail: zounek@phil.muni.cz 